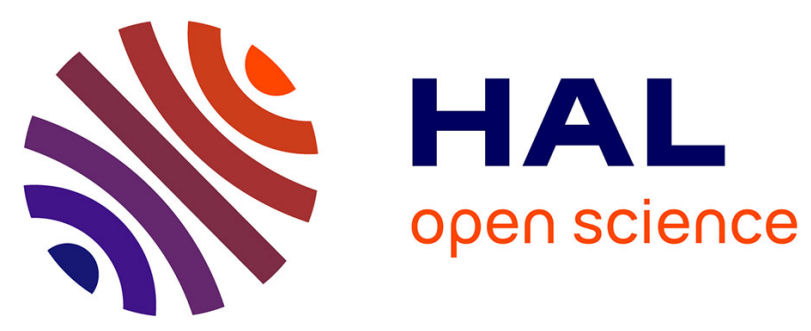

\title{
Preoperative nomogram to predict the likelihood of complications after radical nephroureterectomy
}

Jay D. Raman, Yu-Kuan Lin, Shahrokh F. Shariat, Laura-Maria Krabbe, Vitaly Margulis, Alex Arnouk, Costas D. Lallas, Edouard J. Trabulsi, Sarah J. Drouin, Morgan Rouprêt, et al.

\section{To cite this version:}

Jay D. Raman, Yu-Kuan Lin, Shahrokh F. Shariat, Laura-Maria Krabbe, Vitaly Margulis, et al.. Preoperative nomogram to predict the likelihood of complications after radical nephroureterectomy. BJU international, 2017, 119 (2), pp.268-275. 10.1111/bju.13556 . hal-01558316

HAL Id: hal-01558316 https://hal-univ-rennes1.archives-ouvertes.fr/hal-01558316

Submitted on 1 Feb 2018

HAL is a multi-disciplinary open access archive for the deposit and dissemination of scientific research documents, whether they are published or not. The documents may come from teaching and research institutions in France or abroad, or from public or private research centers.
L'archive ouverte pluridisciplinaire HAL, est destinée au dépôt et à la diffusion de documents scientifiques de niveau recherche, publiés ou non, émanant des établissements d'enseignement et de recherche français ou étrangers, des laboratoires publics ou privés. 
Received Date : 21-Feb-2016

Revised Date : 07-May-2016

Accepted Date : 17-Jun-2016

Article type : Original Article

\section{PREOPERATIVE NOMOGRAM TO PREDICT LIKELIHOOD OF COMPLICATIONS FOLLOWING RADICAL NEPHROURETERECTOMY}

Jay D. Raman ${ }^{1,9}$, Yu-Kuan Lin ${ }^{1}$, Shahrokh F. Shariat ${ }^{2}$, Laura-Maria Krabbe ${ }^{3}$, Vitaly Margulis $^{3}$, Alex Arnouk ${ }^{4}$, Costas D. Lallas ${ }^{4}$, Edouard J. Trabulsi ${ }^{4}$, Sarah J. Drouin ${ }^{5}$, Morgan Rouprêt ${ }^{5}$, Gregory Bozzini ${ }^{6}$, Pierre Colin ${ }^{6}$, Benoit Peyronnet ${ }^{7}$, Karim Bensalah $^{7}$, Kari Bailey ${ }^{8}$, David Canes ${ }^{8}$, Tobias Klatte ${ }^{2}$

${ }^{1}$ Division of Urology, Penn State Milton S. Hershey Medical Center, Hershey, PA, USA

${ }^{2}$ Department of Urology, Medical University of Vienna, Vienna, Austria

${ }^{3}$ Department of Urology, University of Texas Southwestern Medical Center, Dallas, TX, USA

${ }^{4}$ Department of Urology, Sidney Kimmel Medical College at Thomas Jefferson University,

Philadelphia, PA, USA

${ }^{5}$ Department of Urology, Pitie Salpétrière Hospital, AP-HP, University Paris 6, Paris, France

${ }_{7}^{6}$ Department of Urology, Centre Hospitalier Regional Universitaire de Lille, Lille, France

${ }^{7}$ Department of Urology, University of Rennes, Rennes, France

${ }^{8}$ Department of Urology, Lahey Hospital and Medical Center, Burlington, MA, USA

${ }^{9}$ Address for Correspondence:

Jay D. Raman, MD

Associate Professor of Surgery

Chief, Division of Urology

Penn State Milton S. Hershey Medical Center

500 University Drive, c4830B

Hershey, PA 17033

Ph: 717-531-6979

Fax: 717-531-4475

Email: jraman@hmc.psu.edu

Key words: upper-tract urothelial carcinoma (UTUC); complications; Clavien-Dindo classification; nomogram

The author declare no conflicts of interest regarding this manuscript.

Running title: Nomogram to predict RNU complications

This article has been accepted for publication and undergone full peer review but has not been through the copyediting, typesetting, pagination and proofreading process, which may lead to differences between this version and the Version of Record. Please cite this article as doi: 10.1111/bju.13556 


\begin{abstract}
OBJECTIVES: To construct a nomogram based on preoperative variables to better predict the likelihood of a complication occurring within 30-days of radical nephroureterectomy (RNU).
\end{abstract}

PATIENTS AND METHODS: The charts of 731 patients undergoing RNU at 8 academic medical centers between 2002 and 2014 were reviewed. Preoperative clinical, demographic, and comorbidity indices were collected. Complications occurring within 30-days of surgery were graded using the modified Clavien-Dindo scale. Multivariate logistic regression determined the association between preoperative variables and post-RNU complications. A nomogram was created from the reduced multivariate model with internal validation using the bootstrapping technique with 200 repetitions.

RESULTS: 408 men and 323 women with a median age of 70 years and BMI of 27 were included. $75 \%$ of the cohort was of white race, $18 \%$ had an ECOG performance status $\geq 2,20 \%$ had a Charlson Comorbidity Index $>5$, and 50\% had baseline CKD stage III or greater. Overall, 279 patients (38\%) experienced a complication including $61(22 \%)$ with Clavien III or greater events. A multivariate model identified 5 variables associated with complications including patient age, race, ECOG performance status, CKD stage, and Charlson comorbidity index. A preoperative nomogram incorporating these risk factors was constructed with an area under curve of $72.2 \%$. 
CONCLUSIONS: Using standard preoperative variables from this multi-institutional RNU experience, we constructed and validated a nomogram for predicting perioperative complications after RNU. Such information may permit more accurate risk stratification on an individual cases basis prior to major surgery.

\section{INTRODUCTION}

Upper-tract urothelial carcinoma (UTUC) accounts for $5 \%$ of all urothelial malignancies and has an annual incidence in Western countries of approximately 1-2 per $100,000 .^{1,2}$ Surgical excision via radical nephroureterectomy (RNU) with an ipsilateral bladder cuff is considered the referent standard for managing high grade, muscle-invasive, or bulky UTUC. ${ }^{3}$ Contemporary oncologic outcomes following RNU demonstrate durable responses for localized disease. ${ }^{4}$

Many patients with UTUC are elderly and have multiple comorbidities largely owing to associated risk factors for developing this malignancy. For example, in a recent cohort of approximately 100 patients undergoing RNU, Lin and colleagues highlighted a relatively high percentage of competing medical issues including hypertension (61\%), hyperlipidemia (36\%), diabetes $(21 \%)$, as well as baseline cardiac (33\%) and pulmonary (21\%) disease. ${ }^{5}$ As such, perioperative complications may be significant in this cohort of patients.

Objectifying the risk associated with RNU is essential for preoperative patient counseling with regards to recovery and convalescence, delivery of adjuvant therapies and even selection of RNU (versus endoscopic management). To date, however, there is limited data evaluating complications following RNU. A comprehensive review of RNU outcomes published by Rassweiller et al. in 2004 noted major and minor complications rates of 0 to $29 \%$ and 0 to $45 \%$, respectively. ${ }^{6}$ 
Subsequent studies have been conflicting with single institution series noting significantly higher rates of complications than that reported from population-based administrative datasets. Thus, while these studies provide some insight on perioperative complications, translating these observations to improve patient care for individual patients is challenging.

Therefore, our goals in this study were two-fold. Firstly, to better define complications following RNU, we rigorously reviewed 30-day events occurring after surgery using a standardized validated classification system. In doing so, we defined the incidence and severity of complications and identified risk factors associated with these perioperative events. Secondly, we used this information to construct a nomogram based on preoperative variables to predict the likelihood of a perioperative complication within 30-days of RNU. Our belief was such information would permit more personalized counseling for patients prior to RNU surgery.

\section{PATIENTS AND METHODS}

Patient selection. The medical records of 731 patients with clinically localized, non-metastatic UTUC undergoing RNU at 8 academic medical centers between 2002 and 2014 were retrospectively reviewed. All patients had complete preoperative clinical, demographic and comorbidity indices were collected. This study specifically focused on preoperative clinical variables to avoid the inherent confounding impact of final pathologic features which would not be available until after radical nephroureterectomy. RNU was performed via open or minimally invasive technique with regional lymphadenectomy at the discretion of the operating surgeon. All specimens were histologically confirmed to be urothelial carcinoma. 
Grading of complications. Perioperative complications occurring within 30days of surgery were graded using the modified Clavien-Dindo scale. ${ }^{7}$ Minor complications were classified as Clavien II or less, while major complications were Grade III or greater. The number, severity, type, and management of complications were recorded.

Statistical analysis. Continuous data are presented as median and range; and categorical data as number of patients (percentage of sample). The chi-squared or Fisher-exact test evaluated the association between categorical variables, and the Mann Whitney U-test assessed for differences in continuous variables. Analyses were performed to develop a model utilizing preoperative factors for predicting any postoperative complication. Associations were summarized using odds ratios (OR) and $95 \%$ confidence intervals (Cls) from univariable and multivariable logistic regression models. A full multivariable model included all possible predictors, including age, race, gender, ASA score, ECOG performance status, Charlson Comorbidity index (CCl), BMI, individual comorbidities and receipt of neoadjuvant chemotherapy. To exclude variables with limited predictive ability from the full model, a stepwise backward variable selection with the likelihood ratio criterion was used, resulting in a reduced model.

A nomogram containing all variables of the reduced model was created using the R "rms" package, after incorporating restricted cubic splines to model the potential non-linear relationship for age. Discrimination was assessed using the area under receiver operating characteristic curve (AUC-ROC). The apparent 
performance of the model measured by the AUC-ROC was estimated directly from the data set that was used to develop the model and is therefore a biased optimistic estimate of discrimination. A nearly unbiased optimism-corrected estimate of AUCROC was derived using 200 bootstrap resamples as a method of internal validation. Calibration was assessed by comparing the predicted probabilities with the actual observed proportions. All statistical analyses were performed using the R 3.1.1 statistical package (http://cran.r-project.org).

\section{RESULTS}

Clinical characteristics for the 731 patients included in this study stratified by presence of any complications are shown in Table 1.408 men and 323 women with a median age of 70 years (range 26-97) and BMI of 27 were included. $75 \%$ of the cohort was of white race, $50 \%$ had baseline CKD stage III or greater and 25 patients (3\%) received neoadjuvant chemotherapy prior to RNU. Hypertension (54\%), hyperlipidemia (42\%), and cardiac disease (22\%) were the leading concurrent medical diagnoses in our patients. When considering comorbidity indices, ECOG performance status was $>2$ in $18 \%$ of the group. ASA score was $>3$ in $49 \%$ of patients, and $55 \%$ of the cohort had a $\mathrm{CCl}$ score of 4 or greater. Surgical approach included 534 (73\%) by minimally invasive techniques and 197 (27\%) via open approaches.

Overall, 279 patients (38.2\%) experienced a complication including 61 (22\%) with Clavien III or greater events. Hematologic, gastrointestinal, and infectious etiologies comprised over $75 \%$ of complications. There were $7(1 \%)$ mortality cases noted in our cohort within 30 days of RNU. Increasing patient age $(p<0.001)$, white 
race $(p=0.001), E C O G>2(p<0.001)$, increasing $C C I(p<0.001)$, history of pulmonary disease $(p=0.015)$, hypertension $(p=0.019)$, diabetes $(p=0.022)$, hyperlipidemia $(p=0.003)$ and worsening CKD stage $(p<0.001)$ were all associated with post-RNU complications. (Table 1)

Tables 2 and 3 stratify the associations of preoperative variables with minor (Clavien I and II) and major (Clavien > III) complications, respectively. When specifically considering minor complications, increasing patient age $(p<0.001)$, white race $(p<0.001)$, male gender $(p=0.024), E C O G>2(p<0.001)$, increasing $C C I$ $(p=0.001)$, history of pulmonary disease $(p=0.033)$, hypertension $(p=0.023)$, hyperlipidemia $(p=0.001)$ and worsening CKD stage $(p<0.001)$ were all associated with post-RNU events. (Table 2) Analysis of major complications was limited by fewer number of patients $(n=61)$. Nonetheless, in this group, only ECOG $>2$ $(p=0.004)$ and increasing CKD stage $(p=0.021)$ were associated with post-RNU complications. (Table 3)

Table 4 highlights the univariable and multivariable logistic regression to predict the likelihood of complications following RNU. Given the relatively low number of major complications, this analysis considered all complications as outcome variable of interest. The full multivariate model identified 5 variables associated with including patient age, race, ECOG performance status, Charlson comorbidity index, and CKD stage. A reduced model which incorporated variables in the full model with $p$ value of $<0.1$ identified similar variables with a similar AUCROC (72.2\% reduced model vs. $72.9 \%$ full model). 
The reduced multivariate model was used to create a preoperative nomogram. (Figure 2) Use of the nomogram is simple. For example, a 70-year-old (51 pts) Caucasian (37 pts) patient with ECOG performance status of 1 (0 pts), Charlson Comorbidities index of 1 (37 pts), and CKD stage III (22 points) will have a total point value of 147 points which corresponds to a $40 \%$ risk of perioperative complication.

\section{DISCUSSION}

The gold standard therapy for UTUC remains RNU with resection of an ipsilateral bladder cuff. Owing to baseline medical comorbidities inherent in this patient population, perioperative complications are likely to be significant. Defining the likelihood of these complications is essential for adequate patient counseling. ${ }^{8,9}$ Furthermore, such complications may not only impact convalescence and recovery, but may also delay the administration of systemic adjuvant therapies in high risk patients. ${ }^{10}$ This is particularly true when considering that many patients will be pathologically upstaged at RNU with adverse pathologic features portending inferior survival in the absence of additional therapy. ${ }^{11-13}$

In the present study of 731 patients undergoing RNU at 8 academic medical centers, 279 patients (38\%) experienced postoperative complications. Of the 299 total complications, $79 \%$ were minor (Clavien grades I and II) and $21 \%$ were major (Clavien grades III-V). Hematologic, gastrointestinal, and infectious causes accounted for over $75 \%$ of observed events, and the 30 -day mortality rate was just under $1 \%$. Our data are fairly concordant with other carefully annotated single institution series using standardized reporting schemes. 
In 2012, Rajput et al. reviewed their experience of patients undergoing laparoscopic RNU to specifically determine the impact of neoadjuvant chemotherapy on perioperative outcomes. ${ }^{14}$ In this series of 82 patients, 40 (49\%) experienced a post-operative complication of which $85 \%$ (34 of 40 ) were Clavien I and II and the remaining $15 \%$ (6 of 40 ) were Clavien III and IV. No perioperative mortalities were identified and there were no differences observed in patients who received neoadjuvant chemotherapy. A similar single institution series by Lin and colleagues used the modified Clavien-Dindo classification to define the incidence and risk factors associated with perioperative complications occurring within 30 days of RNU. ${ }^{5}$ In this cohort of 92 patients, 35 patients (38\%) experienced complications within 30 days of RNU including 11 (12\%) with major complications. In their multivariate model, only ECOG $\geq 2(\mathrm{OR} 3.9,95 \% \mathrm{Cl} 1.6-7.4, \mathrm{p}<0.001)$ was independently associated with post-RNU complications.

Somewhat distinct, however, from the above studies is data originating from the British Association of Urological Surgeons (BAUS) Registry. ${ }^{15}$ In this registry series encompassing 863 RNU surgeries performed in 110 centers, the reported complication rates were significantly lower than described above. Specifically, the overall complication rate was $15 \%$ of which Clavien > 3 was reported in $4 \%$ and perioperative death noted in 9 patients $(1 \%)$. Similarly low complication rates have been reported in several series originating from population datasets. In 2012, Hanna and colleagues used the United States Nationwide Inpatient Sample (NIS) to identify patients with clinically localized UTUC managed by open RNU or laparoscopic RNU. ${ }^{16}$ They observed no differences in post-operative complications (15\% vs. $17 \%$, $\mathrm{p}=0.24)$ or in-hospital mortality $(0.7 \%$ vs. $1.3 \%, p=0.12)$ between the two 
approaches. Also, in 2012, Ni and colleagues published a systematic review and cumulative analysis of laparoscopic RNU versus open RNU for management of UTUC. ${ }^{17}$ In this paper, complication rates were low without no significant differences in intraoperative complications (4.4\% vs $5.1 \%)$, minor post-operative complications (5.7\% vs. $7.8 \%$ ), major post-operative complications (4.6\% vs $3.8 \%)$, or perioperative mortality (1.6\% vs $0.7 \%$ ) between surgical approaches. Whilst our manuscript did not focus on surgical approach (open vs. MIS) given potential confounding bias, we have similarly found that technique is not associated with postoperative complications. ${ }^{18}$ Specifically, in this prior study including the 732 patients from this manuscript, increased operative duration (OR 8.3, 95\% Cl 3.6 - 10.8, $\mathrm{p}=0.004)$ and transfusion requirement $(\mathrm{OR} 6.8,95 \% \mathrm{Cl} 2.4-8.7, \mathrm{p}=0.009)$ were the sole operative variables associated with post-operative complications after RNU.

Most recently, in 2015 a recent registry based publication reported on the 30day perioperative outcomes of open versus minimally invasive radical nephroureterectomy through investigation of the American College of Surgeons National Surgical Quality Improvement Program Database (ACS-NSQIP). ${ }^{19}$ In this study of 896 patients, $12.7 \%$ of patients experienced a complication within 30 -days of RNU with no difference between operative approaches (open RNU $12.5 \%$ vs. minimally invasive RNU $12.9 \%, p=0.87)$. Ultimately, it is apparent that single or multicenter series that rigorously annotate complications appear to report higher rates particularly of Clavien I and II complications. One has to wonder if the differences in reported rates (particularly lower in the registry trials) are a function of recall bias amongst other factors. 
As a result of the biological aggressiveness of UTUC with the potential for subsequent disease recurrence, contemporary oncological outcomes after RNU remain poor especially for advanced UTUC patients. The UTUC collaboration reported results from 1363 patients treated with RNU at 12 academic centers and found that 5-year recurrence-free and cancer-specific survival probabilities were $69 \%$ and $73 \%$, respectively. ${ }^{4}$ These observations highlight that current treatment paradigms may need to be augmented with multimodal therapy, including perioperative chemotherapy. ${ }^{20}$ However as we have previously published, a relatively low percentage of patients with adverse pathological features after RNU actually receive adjuvant chemotherapy. ${ }^{10}$ The rationale behind the infrequent use of chemotherapy in these high risk patients was unclear, but likely includes patient and physician preference, decreased renal function and the potential confounding impact of operative complications. ${ }^{21}$

Improving the quality of the healthcare delivery system has been a subject of importance worldwide. A huge emphasis has been placed on reducing postoperative complications and thus reducing costs and improving the delivery of care. The lack of a standardized reporting system for postoperative complications in the field of urology and many other urological specialties makes interpreting literature and measuring surgical outcomes difficult. ${ }^{8,9}$ However, it is worth noting that the use of grading complication system is slowly gaining impetus.

There are several noteworthy findings in this study. Congruent to some other published literature, the overall complication rate after RNU approached $40 \%$. This study is also the first to associate age, race, ECOG performance status, CKD stage, and Charlson comorbidity index as independent predictors of perioperative complications. Lastly, similar to other studies, we also found that BMI was not a 
factor in operative duration, estimated blood loss and complications rates. ${ }^{14,22}$ Given the rarity of UTUC, it is unlikely that a randomized trial examining perioperative outcomes of RNU will be conducted.

Nomograms are currently considered the most accurate tool to predict outcomes after surgical treatment and may be especially beneficial for the management of this uncommon malignancy where evidence-based medicine is lacking. ${ }^{23}$ By assigning points to the five preoperative variables, one can easily estimate the likelihood of a perioperative complication. Predictive tools such this this nomogram can enable clinicians to accurately evaluate a patient's situation to counsel more objectively and to guide personalized clinical decision making regarding management options. This information may encourage the use of endoscopic therapies and potentially defer RNU in certain high risk patients. Furthermore, we hope that this nomogram will also allow for the use of a progressive post-operative pathway, which has been proven beneficial in reducing the lengths of stay after surgical procedures of many types. ${ }^{24}$ In this regard, we believe that creation of a nomogram yields incremental information beyond simply identifying risk factors for complications.

We acknowledge several limitations in this study. First, our study was a retrospective study of medical records. Thus, we suspect a degree of under reporting and under realization of minor complications which may not have been annotated in records. In addition, the multicenter nature could contribute to variations in how complications are both graded and managed. Secondly, our nomogram was internally validated and further direction is geared to external validation through accrual of a large international multicenter cohort. Thirdly, the number of major complications events was fairly low thereby rendering nomogram creation impossible 
for these specific events which may impact decisions most significantly. Finally, these experiences are reflective of academic medical center urologic practices which may suffer from referral bias. This occurrence may account for higher complication rates observed in this study as well as other large tertiary referral centers compared to population registries. Despite these limitations, to our best knowledge, this study presents the most critical appraisal to date of complications that occur secondary to radical surgery for UTUC and the first to provide a nomogram for use in the preoperative setting.

\section{CONCLUSION}

Using standard preoperative variables from this multi-institutional UTUC database, we found that the postoperative complication following RNU approaches 40\%. Patient's age, race, ECOG performance status, CKD stage and Charlson comorbidity index were all independent predictive factors. These data were used to construct and validate a preoperative nomogram for predicting perioperative complications after RNU. We hope such information will permit more accurate risk stratification on an individual cases basis prior to radical surgery.

\section{FIGURES}

Figure 1: Calibration plot for preoperative nomogram with internal validation using the bootstrapping technique with 200 repetitions.

Figure 2: Nomogram predicting complication within 30 days of RNU (from reduced multivariable model) 


\section{TABLES}

Table 1. Association of preoperative variables with perioperative complications with 30-days of RNU.

Table 2. Association of preoperative variables with minor complications (Clavien I and II)

Table 3. Association of preoperative variables with major complications (Clavien > III)

Table 4. Univariable and multivariable logistic regression for prediction of total complications

\section{REFERENCES}

1. Siegel RL, Miller KD, Jemal A. Cancer statistics, 2015. CA Cancer J Clin. JanFeb 2015;65(1):5-29.

2. Munoz JJ, Ellison LM. Upper tract urothelial neoplasms: incidence and survival during the last 2 decades. J Urol. Nov 2000;164(5):1523-1525.

3. Raman JD, Scherr DS. Management of patients with upper urinary tract transitional cell carcinoma. Nat Clin Pract Urol. Aug 2007;4(8):432-443.

4. Margulis V, Shariat SF, Matin SF, et al. Outcomes of radical nephroureterectomy: a series from the Upper Tract Urothelial Carcinoma Collaboration. Cancer. Mar 15 2009;115(6):1224-1233.

5. Lin YK, Deliere A, Lehman K, Harpster LE, Kaag MG, Raman JD. Critical analysis of 30 day complications following radical nephroureterectomy for upper tract urothelial carcinoma. The Canadian journal of urology. Aug 2014;21(4):7369-7373.

6. Rassweiler JJ, Schulze M, Marrero R, Frede T, Palou Redorta J, Bassi P. Laparoscopic nephroureterectomy for upper urinary tract transitional cell carcinoma: is it better than open surgery? Eur Urol. Dec 2004;46(6):690-697. 
7. Dindo D, Demartines N, Clavien PA. Classification of surgical complications: a new proposal with evaluation in a cohort of 6336 patients and results of a survey. Annals of surgery. Aug 2004;240(2):205-213.

8. Mitropoulos D, Artibani W, Graefen M, et al. Reporting and grading of complications after urologic surgical procedures: an ad hoc EAU guidelines panel assessment and recommendations. Eur Urol. Feb 2012;61(2):341-349.

9. Martin RC, 2nd, Brennan MF, Jaques DP. Quality of complication reporting in the surgical literature. Annals of surgery. Jun 2002;235(6):803-813.

10. Raman JD, Lin YK, Kaag M, et al. High rates of advanced disease, complications, and decline of renal function after radical nephroureterectomy. Urol Oncol. Jan 2014;32(1):47 e49-14.

11. Hall MC, Womack S, Sagalowsky AI, Carmody T, Erickstad MD, Roehrborn CG. Prognostic factors, recurrence, and survival in transitional cell carcinoma of the upper urinary tract: a 30-year experience in 252 patients. Urology. Oct 1998;52(4):594-601.

12. Jeldres $\mathrm{C}$, Sun $\mathrm{M}$, Isbarn $\mathrm{H}$, et al. A population-based assessment of perioperative mortality after nephroureterectomy for upper-tract urothelial carcinoma. Urology. Feb 2010;75(2):315-320.

13. McNeill SA, Chrisofos M, Tolley DA. The long-term outcome after laparoscopic nephroureterectomy: a comparison with open nephroureterectomy. BJU Int. Oct 2000;86(6):619-623.

14. Rajput MZ, Kamat AM, Clavell-Hernandez J, et al. Perioperative outcomes of laparoscopic radical nephroureterectomy and regional lymphadenectomy in patients with upper urinary tract urothelial carcinoma after neoadjuvant chemotherapy. Urology. Jul 2011;78(1):61-67. 
15. Connolly SS, Rochester MA, Baus. Nephroureterectomy surgery in the UK in 2012: British Association of Urological Surgeons (BAUS) Registry data. BJU Int. Nov 2015;116(5):780-790.

16. Hanna N, Sun M, Trinh QD, et al. Propensity-score-matched comparison of perioperative outcomes between open and laparoscopic nephroureterectomy: a national series. Eur Urol. Apr 2012;61(4):715-721.

17. Ni S, Tao W, Chen Q, et al. Laparoscopic versus open nephroureterectomy for the treatment of upper urinary tract urothelial carcinoma: a systematic review and cumulative analysis of comparative studies. Eur Urol. Jun 2012;61(6):1142-1153.

18. Lin YK, Lehman E, Krabbe LM, et al. Operative durattion and intraoperative transfusion requirement are associated with patients developing complications following radical nephroureterectomy. Can J Urol 201421 (4) 7409.

19. Hanske J, Sanchez A, Schmid M, et al. A Comparison of 30-Day Perioperative Outcomes in Open Versus Minimally Invasive Nephroureterectomy for Upper Tract Urothelial Carcinoma: Analysis of 896 Patients from the American College of Surgeons-National Surgical Quality Improvement Program Database. Journal of endourology / Endourological Society. Sep 2015;29(9):1052-1058.

20. Leow JJ, Orsola A, Chang SL, Bellmunt J. A contemporary review of management and prognostic factors of upper tract urothelial carcinoma. Cancer Treat Rev. Apr 2015;41(4):310-319. 
21. Brown GA, Busby JE, Wood CG, et al. Nephroureterectomy for treating upper urinary tract transitional cell carcinoma: Time to change the treatment paradigm? BJU Int. Dec 2006;98(6):1176-1180.

22. Brown JA, Chenven E, Looney SW, et al. Hand-assisted laparoscopic nephroureterectomy (HALNU): an assessment of the impact of obesity in 50 procedures. J Laparoendosc Adv Surg Tech A. Feb 2008;18(1):61-68.

23. Sonpavde G, Pond GR, Fougeray R, Bellmunt J. Nomogram to predict the benefit from salvage systemic therapy for advanced urothelial carcinoma. BJU Int. Jun 2015;115(6):854-855.

24. Khemees TA, Nasser SM, Abaza R. Clinical pathway after robotic nephroureterectomy: omission of pelvic drain with next-day catheter removal and discharge. Urology. Apr 2014;83(4):818-823. 
Table 1 Association of preoperative variables with complications at 30 days

\begin{tabular}{|c|c|c|c|c|c|c|}
\hline Variable & & & $\begin{array}{l}\text { No Complication } 30 \\
\text { days }\end{array}$ & Complication 30 days & Total & p-value \\
\hline $\mathrm{N}$ & & - & $452(61.8)$ & $279(38.2)$ & $731(100.0)$ & - \\
\hline Age & Median (Range) & - & $68(26-97)$ & $72(27-92)$ & $70(26-97)$ & $<0.001$ \\
\hline Race & $\mathrm{N}(\%)$ & $\begin{array}{l}\text { White } \\
\text { Black } \\
\text { Other }\end{array}$ & $\begin{array}{l}315(69.8) \\
121(26.8) \\
15(3.3) \\
\end{array}$ & $\begin{array}{l}230(82.4) \\
43(15.4) \\
6(2.2)\end{array}$ & $\begin{array}{l}545(74.7) \\
164(22.5) \\
21(2.9)\end{array}$ & 0.001 \\
\hline Gender & $\mathrm{N}(\%)$ & $\begin{array}{l}\text { Male } \\
\text { Female }\end{array}$ & $\begin{array}{l}242(53.5) \\
210(46.5) \\
\end{array}$ & $\begin{array}{l}166(59.5) \\
113(40.5)\end{array}$ & $\begin{array}{l}408(55.8) \\
323(44.2)\end{array}$ & 0.115 \\
\hline ASA Score & $\mathrm{N}(\%)$ & $\begin{array}{l}1-2 \\
3-4\end{array}$ & $\begin{array}{l}240(53.1) \\
212(46.9) \\
\end{array}$ & $\begin{array}{l}129(46.2) \\
150(53.8)\end{array}$ & $\begin{array}{l}369(50.5) \\
362(49.5)\end{array}$ & 0.071 \\
\hline ECOG & $\mathrm{N}(\%)$ & $\begin{array}{l}0-1 \\
2-4\end{array}$ & $\begin{array}{l}411(90.9) \\
41(9.1)\end{array}$ & $\begin{array}{l}191(68.5) \\
88(31.5)\end{array}$ & $\begin{array}{l}602(82.4) \\
129(17.6)\end{array}$ & $<0.001$ \\
\hline Charlson Comorbidity Index & $\mathrm{N}(\%)$ & $\begin{array}{l}0-1 \\
2-3 \\
4-5 \\
>5 \\
\end{array}$ & $\begin{array}{l}33(7.3) \\
195(43.1) \\
162(35.8) \\
62(13.7) \\
\end{array}$ & $\begin{array}{l}22(7.9) \\
81(29.0) \\
94(33.7) \\
82(29.4) \\
\end{array}$ & $\begin{array}{l}55(7.5) \\
276(37.8) \\
256(35.0) \\
144(19.7) \\
\end{array}$ & $<0.001$ \\
\hline $\mathrm{BMI}$ & Median (Range) & - & $27(15-50)$ & $27(16-62)$ & $27(15-62)$ & 0.342 \\
\hline Pulm Dz & $\mathrm{N}(\%)$ & $\begin{array}{l}\text { No } \\
\text { Yes }\end{array}$ & $\begin{array}{l}404(89.4) \\
58(10.6) \\
\end{array}$ & $\begin{array}{l}232(83.2) \\
47(16.8) \\
\end{array}$ & $\begin{array}{l}636(87.0) \\
95(13.0) \\
\end{array}$ & 0.015 \\
\hline CAD & $\mathrm{N}(\%)$ & $\begin{array}{l}\text { No } \\
\text { Yes }\end{array}$ & $\begin{array}{l}359(79.4) \\
93(20.6) \\
\end{array}$ & $\begin{array}{l}207(74.5) \\
71(25.5) \\
\end{array}$ & $\begin{array}{l}566(77.5) \\
164(22.5) \\
\end{array}$ & 0.119 \\
\hline HTN & $\mathrm{N}(\%)$ & $\begin{array}{l}\text { No } \\
\text { Yes }\end{array}$ & $\begin{array}{l}225(49.8) \\
227(50.2) \\
\end{array}$ & $\begin{array}{l}114(40.9) \\
165(59.1) \\
\end{array}$ & $\begin{array}{l}339(46.4) \\
392(53.6) \\
\end{array}$ & 0.019 \\
\hline DM & $\mathrm{N}(\%)$ & $\begin{array}{l}\text { No } \\
\text { Yes }\end{array}$ & $\begin{array}{l}386(85.4) \\
66(14.6) \\
\end{array}$ & $\begin{array}{l}220(78.9) \\
59(21.1) \\
\end{array}$ & $\begin{array}{l}606(82.9) \\
125(17.1) \\
\end{array}$ & 0.022 \\
\hline Hyperlipidemia & $\mathrm{N}(\%)$ & $\begin{array}{l}\text { No } \\
\text { Yes }\end{array}$ & $\begin{array}{l}283(62.6) \\
169(37.4) \\
\end{array}$ & $\begin{array}{l}144(51.6) \\
135(48.4) \\
\end{array}$ & $\begin{array}{l}427(58.4) \\
304(31.6) \\
\end{array}$ & 0.003 \\
\hline CKD Stage & $\mathrm{N}(\%)$ & $\begin{array}{l}1 \\
2 \\
3 \\
\end{array}$ & $\begin{array}{l}69(15.3) \\
182(40.3) \\
184(40.7) \\
\end{array}$ & $\begin{array}{l}48(17.2) \\
26(24.0) \\
131(47.0)\end{array}$ & $\begin{array}{l}117(16.0) \\
249(34.1) \\
315(43.1)\end{array}$ & $<0.001$ \\
\hline
\end{tabular}




\begin{tabular}{|l|l|l|l|l|l|l|}
\hline & & 4 & $10(2.2)$ & $26(9.3)$ & $36(4.9)$ & $14(1.9)$ \\
\hline Neoadjuvant chemo & $\mathrm{N}(\%)$ & 5 & $7(1.5)$ & $7(2.5)$ & $702(96.6)$ & $25(3.4)$ \\
\hline
\end{tabular}

Table 2 Association of preoperative variables with minor complications (Clavien I and II)

\begin{tabular}{|c|c|c|c|c|c|c|}
\hline Variable & & & \begin{tabular}{|l|} 
No minor \\
complication
\end{tabular} & Minor complication & Total & $p$-value \\
\hline $\mathrm{N}$ & & - & $493(67.4)$ & $238(32.6)$ & $731(100.0)$ & - \\
\hline Age & Median (Range) & - & $68(26-97)$ & $72.5(27-92)$ & $70(26-97)$ & $<0.001$ \\
\hline Race & $\mathrm{N}(\%)$ & $\begin{array}{l}\text { White } \\
\text { Black } \\
\text { Other }\end{array}$ & $\begin{array}{l}342(69.5) \\
133(27.0) \\
17(3.5)\end{array}$ & \begin{tabular}{|l|}
$203(85.3)$ \\
$31(13.0)$ \\
$4(1.7)$
\end{tabular} & $\begin{array}{l}545(74.7) \\
164(22.5) \\
21(2.9)\end{array}$ & $<0.001$ \\
\hline Gender & $\mathrm{N}(\%)$ & \begin{tabular}{|l|} 
Male \\
Female \\
\end{tabular} & $\begin{array}{l}261(52.9) \\
232(47.1) \\
\end{array}$ & $\begin{array}{l}147(61.8) \\
91(38.2)\end{array}$ & $\begin{array}{l}408(55.8) \\
323(44.2)\end{array}$ & 0.024 \\
\hline ASA Score & $N(\%)$ & \begin{tabular}{|l|}
$1-2$ \\
$3-4$ \\
\end{tabular} & $\begin{array}{l}258(52.3) \\
235(47.7) \\
\end{array}$ & $\begin{array}{l}111(46.6) \\
127(53.4) \\
\end{array}$ & $\begin{array}{l}369(50.5) \\
362(49.5)\end{array}$ & 0.149 \\
\hline ECOG & $\mathrm{N}(\%)$ & $\begin{array}{l}0-1 \\
2-4\end{array}$ & $\begin{array}{l}441(89.5) \\
52(10.5)\end{array}$ & $\begin{array}{l}161(67.6) \\
77(32.4)\end{array}$ & $\begin{array}{l}602(82.4) \\
129(17.6)\end{array}$ & $<0.001$ \\
\hline Charlson Comorbidity Index & $\mathrm{N}(\%)$ & $\begin{array}{l}0-1 \\
2-3 \\
4-5 \\
>5\end{array}$ & $\begin{array}{l}41(8.3) \\
203(41.2) \\
171(34.7) \\
78(15.8)\end{array}$ & \begin{tabular}{|l|}
$14(5.9)$ \\
$73(30.7)$ \\
$85(35.7)$ \\
$66(27.7)$
\end{tabular} & $\begin{array}{l}55(7.5) \\
276(37.8) \\
256(35.0) \\
144(19.7)\end{array}$ & 0.001 \\
\hline $\mathrm{BMI}$ & Median (Range) & - & $27(15-50)$ & $27(16-62)$ & $27(15-62)$ & 0.664 \\
\hline Pulm Dz & $\mathrm{N}(\%)$ & $\begin{array}{l}\text { No } \\
\text { Yes }\end{array}$ & $\begin{array}{l}438(88.8) \\
55(11.2)\end{array}$ & $\begin{array}{l}198(83.2) \\
40(16.8)\end{array}$ & $\begin{array}{l}636(87.0) \\
95(13.0)\end{array}$ & 0.033 \\
\hline CAD & $\mathrm{N}(\%)$ & $\begin{array}{l}\text { No } \\
\text { Yes }\end{array}$ & $\begin{array}{l}390(79.1) \\
103(20.9)\end{array}$ & $\begin{array}{l}176(74.3) \\
61(25.7)\end{array}$ & $\begin{array}{l}566(77.5) \\
164(22.5)\end{array}$ & 0.142 \\
\hline HTN & $\mathrm{N}(\%)$ & $\begin{array}{l}\text { No } \\
\text { Yes }\end{array}$ & $\begin{array}{l}243(49.3) \\
250(50.7)\end{array}$ & $\begin{array}{l}96(40.3) \\
142(59.7)\end{array}$ & $\begin{array}{l}339(46.4) \\
392(53.6)\end{array}$ & 0.023 \\
\hline DM & $\mathrm{N}(\%)$ & No & $418(84.8)$ & $188(79.0)$ & $606(82.9)$ & 0.051 \\
\hline
\end{tabular}




\begin{tabular}{|c|c|c|c|c|c|c|}
\hline & & Yes & 75 (15.2) & $50(21.0)$ & $125(17.1)$ & \\
\hline Hyperlipidemia & $N(\%)$ & $\begin{array}{l}\text { No } \\
\text { Yes }\end{array}$ & $\begin{array}{l}307(62.3) \\
186(37.7) \\
\end{array}$ & $\begin{array}{l}120(50.4) \\
118(49.6) \\
\end{array}$ & $\begin{array}{l}427(58.4) \\
304(31.6) \\
\end{array}$ & 0.002 \\
\hline CKD Stage & $\mathrm{N}(\%)$ & $\begin{array}{l}1 \\
2 \\
3 \\
4 \\
5\end{array}$ & $\begin{array}{l}73(14.8) \\
196(39.8) \\
202(41.0) \\
14(2.8) \\
8(1.6) \\
\end{array}$ & $\begin{array}{l}44(18.5) \\
53(22.3) \\
113(47.5) \\
22(9.2) \\
6(2.5) \\
\end{array}$ & $\begin{array}{l}117(16.0) \\
249(34.1) \\
315(43.1) \\
36(4.9) \\
14(1.9) \\
\end{array}$ & $<0.001$ \\
\hline Neoadjuvant chemo & $\mathrm{N}(\%)$ & $\begin{array}{l}\text { No } \\
\text { Yes }\end{array}$ & $\begin{array}{l}470(96.1) \\
19(3.9)\end{array}$ & $\begin{array}{l}232(97.5) \\
6(2.5)\end{array}$ & $\begin{array}{l}702(96.6) \\
25(3.4)\end{array}$ & 0.343 \\
\hline
\end{tabular}

Table 3 Association of preoperative variables with major complications (Clavien > III)

\begin{tabular}{|c|c|c|c|c|c|c|}
\hline Variable & & & $\begin{array}{l}\text { No major } \\
\text { complication }\end{array}$ & Major complication & Total & $p$-value \\
\hline $\mathrm{N}$ & & - & 670 (91.7) & $61(8.3)$ & $731(100.0)$ & - \\
\hline Age & Median (Range) & - & $70(26-97)$ & $69(44-90)$ & $70(26-97)$ & 0.779 \\
\hline Race & $N(\%)$ & \begin{tabular}{|l|} 
White \\
Black \\
Other \\
\end{tabular} & $\begin{array}{l}500(74.7) \\
151(22.6) \\
18(2.7) \\
\end{array}$ & \begin{tabular}{|l|}
$45(73.8)$ \\
$13(21.3)$ \\
$3(4.9)$ \\
\end{tabular} & $\begin{array}{l}545(74.7) \\
164(22.5) \\
21(2.9)\end{array}$ & 0.603 \\
\hline Gender & $\mathrm{N}(\%)$ & \begin{tabular}{|l|} 
Male \\
Female \\
\end{tabular} & $\begin{array}{l}377(56.3) \\
293(43.7) \\
\end{array}$ & \begin{tabular}{|l|}
$31(50.8)$ \\
$30(49.2)$ \\
\end{tabular} & $\begin{array}{l}408(55.8) \\
323(44.2) \\
\end{array}$ & 0.412 \\
\hline ASA Score & $N(\%)$ & $\begin{array}{l}1-2 \\
3-4 \\
\end{array}$ & \begin{tabular}{|l|}
$345(51.5)$ \\
325 (48.5) \\
\end{tabular} & \begin{tabular}{|l|}
$24(39.3)$ \\
$37(60.7)$ \\
\end{tabular} & $\begin{array}{l}369(50.5) \\
362(49.5)\end{array}$ & 0.069 \\
\hline ECOG & $N(\%)$ & $\begin{array}{l}0-1 \\
2-4 \\
\end{array}$ & \begin{tabular}{|l|}
$560(83.6)$ \\
$110(16.4)$ \\
\end{tabular} & \begin{tabular}{|l|}
42 (68.9) \\
$19(31.1)$ \\
\end{tabular} & $\begin{array}{l}602(82.4) \\
129(17.6) \\
\end{array}$ & 0.004 \\
\hline Charlson Comorbidity Index & $\mathrm{N}(\%)$ & $\begin{array}{l}0-1 \\
2-3 \\
4-5 \\
>5 \\
\end{array}$ & $\begin{array}{l}47(7.0) \\
264(39.4) \\
239(35.7) \\
120(17.9) \\
\end{array}$ & \begin{tabular}{|l|}
$8(13.1)$ \\
$12(19.7)$ \\
$17(27.9)$ \\
$24(39.3)$ \\
\end{tabular} & $\begin{array}{l}55(7.5) \\
276(37.8) \\
256(35.0) \\
144(19.7)\end{array}$ & $<0.001$ \\
\hline BMI & Median (Range) & - & $27(15-50)$ & $28(19-62)$ & $27(15-62)$ & 0.204 \\
\hline Pulm Dz & $\mathrm{N}(\%)$ & No & $587(87.6)$ & $49(80.3)$ & $636(87.0)$ & 0.105 \\
\hline
\end{tabular}




\begin{tabular}{|c|c|c|c|c|c|c|}
\hline & & Yes & $83(12.4)$ & 12 (19.7) & $95(13.0)$ & \\
\hline CAD & $\mathrm{N}(\%)$ & $\begin{array}{l}\text { No } \\
\text { Yes }\end{array}$ & $\begin{array}{l}518(77.4) \\
151(22.6)\end{array}$ & $\begin{array}{l}48(78.7) \\
13(21.3)\end{array}$ & $\begin{array}{l}566(77.5) \\
164(22.5)\end{array}$ & 0.821 \\
\hline HTN & $\mathrm{N}(\%)$ & $\begin{array}{l}\text { No } \\
\text { Yes }\end{array}$ & $\begin{array}{l}314(46.9) \\
356(53.1) \\
\end{array}$ & $\begin{array}{l}25(41.0) \\
36(59.0) \\
\end{array}$ & $\begin{array}{l}339(46.4) \\
392(53.6) \\
\end{array}$ & 0.378 \\
\hline $\mathrm{DM}$ & $\mathrm{N}(\%)$ & $\begin{array}{l}\text { No } \\
\text { Yes }\end{array}$ & $\begin{array}{l}560(83.6) \\
110(16.4)\end{array}$ & $\begin{array}{l}46(75.4) \\
15(24.6)\end{array}$ & $\begin{array}{l}606(82.9) \\
125(17.1)\end{array}$ & 0.105 \\
\hline Hyperlipidemia & $\mathrm{N}(\%)$ & $\begin{array}{l}\text { No } \\
\text { Yes }\end{array}$ & $\begin{array}{l}391(58.4) \\
279(41.6)\end{array}$ & $\begin{array}{l}36(59.0) \\
25(41.0)\end{array}$ & $\begin{array}{l}427(58.4) \\
304(31.6)\end{array}$ & 0.920 \\
\hline CKD Stage & $\mathrm{N}(\%)$ & $\begin{array}{l}1 \\
2 \\
3 \\
4 \\
5\end{array}$ & $\begin{array}{l}108(16.1) \\
234(34.9) \\
288(43.0) \\
28(4.2) \\
12(1.8)\end{array}$ & $\begin{array}{l}9(14.8) \\
15(24.6) \\
27(44.3) \\
8(13.1) \\
2(3.3)\end{array}$ & $\begin{array}{l}117(16.0) \\
249(34.1) \\
315(43.1) \\
36(4.9) \\
14(1.9)\end{array}$ & 0.021 \\
\hline Neoadjuvant chemo & $\mathrm{N}(\%)$ & $\begin{array}{l}\text { No } \\
\text { Yes }\end{array}$ & $\begin{array}{l}645(96.7) \\
22(3.3)\end{array}$ & $\begin{array}{l}57(95.0) \\
3(5.0)\end{array}$ & $\begin{array}{l}702(96.6) \\
25(3.4)\end{array}$ & 0.488 \\
\hline
\end{tabular}

Table 4 Univariable and multivariable logistic regression for prediction of total complications

\begin{tabular}{|c|c|c|c|c|c|c|c|c|c|c|}
\hline & & \multicolumn{3}{|c|}{ Univariable } & \multicolumn{3}{|c|}{ Multivariable (full) } & \multicolumn{3}{|c|}{ Multivariable (reduced) } \\
\hline Variable & & OR & $95 \% \mathrm{Cl}$ & $\mathbf{p}$ & OR & $95 \% \mathrm{Cl}$ & $\mathbf{p}$ & OR & $95 \% \mathrm{Cl}$ & $\mathbf{p}$ \\
\hline Age & Continuous & 1.03 & $1.02-1.04$ & $<0.001$ & 1.02 & $1.002-1.04$ & 0.031 & 1.02 & $1.001-1.03$ & 0.040 \\
\hline \multirow[t]{3}{*}{ Race } & White & 1.00 & & & 1.00 & & & 1.00 & & \\
\hline & Black & 0.49 & $0.33-0.72$ & $<0.001$ & 0.58 & $0.37-0.92$ & 0.019 & 0.55 & $0.36-0.85$ & 0.007 \\
\hline & Other & 0.55 & $0.21-1.43$ & 0.220 & 0.82 & $0.29-2.30$ & 0.700 & 0.77 & $0.28-2.16$ & 0.627 \\
\hline \multirow[t]{2}{*}{ Gender } & Male & 1.00 & & & 1.00 & & & - & - & - \\
\hline & Female & 0.78 & $0.58-1.06$ & 0.115 & 0.86 & 0.61-1.23 & 0.411 & & & \\
\hline \multirow[t]{2}{*}{ ASA Score } & $1-2$ & 1.00 & & & 1.00 & & & - & - & - \\
\hline & $3-4$ & 1.32 & $0.98-1.78$ & 0.072 & 0.96 & 0.66-1.39 & 0.823 & & & \\
\hline \multirow[t]{2}{*}{ ECOG } & $0-1$ & 1.00 & & & 1.00 & & & 1.00 & & \\
\hline & $2-4$ & 4.62 & 3.07-6.95 & $<0.001$ & 3.60 & 2.32-5.59 & $<0.001$ & 3.68 & 2.38-5.68 & $<0.001$ \\
\hline Charlson & $0-1$ & 1.00 & & & 1.00 & & & 1.00 & & \\
\hline
\end{tabular}




\begin{tabular}{|c|c|c|c|c|c|c|c|c|c|c|}
\hline $\begin{array}{l}\text { Comorbidity } \\
\text { Index }\end{array}$ & $\begin{array}{l}2-3 \\
4-5 \\
>5\end{array}$ & $\begin{array}{l}0.62 \\
0.87 \\
1.98\end{array}$ & $\begin{array}{l}0.34-1.13 \\
0.48-1.58 \\
1.05-3.73\end{array}$ & $\begin{array}{l}0.121 \\
0.648 \\
0.034\end{array}$ & $\begin{array}{l}0.54 \\
0.69 \\
1.16\end{array}$ & $\begin{array}{l}0.28-1.03 \\
0.36-1.32 \\
0.57-2.38\end{array}$ & $\begin{array}{l}0.061 \\
0.258 \\
0.685\end{array}$ & $\begin{array}{l}0.56 \\
0.74 \\
1.30\end{array}$ & $\begin{array}{l}0.30-1.05 \\
0.39-1.39 \\
0.66-2.58\end{array}$ & $\begin{array}{l}0.070 \\
0.344 \\
0.449\end{array}$ \\
\hline BMI & Continuous & 1.02 & $0.99-1.05$ & 0.246 & 1.01 & $0.98-1.05$ & 0.403 & - & - & - \\
\hline Pulm Dz & $\begin{array}{l}\text { No } \\
\text { Yes }\end{array}$ & $\begin{array}{l}1.00 \\
1.71\end{array}$ & $1.11-2.63$ & 0.016 & $\begin{array}{l}1.00 \\
1.23\end{array}$ & $0.74-2.03$ & 0.431 & - & - & - \\
\hline CAD & $\begin{array}{l}\text { No } \\
\text { Yes }\end{array}$ & $\begin{array}{l}1.00 \\
1.32 \\
\end{array}$ & $0.93-1.89$ & 0.119 & $\begin{array}{l}1.00 \\
0.85\end{array}$ & $0.54-1.34$ & 0.486 & - & - & - \\
\hline HTN & $\begin{array}{l}\text { No } \\
\text { Yes }\end{array}$ & $\begin{array}{l}1.00 \\
1.44 \\
\end{array}$ & $1.06-1.94$ & 0.019 & $\begin{array}{l}1.00 \\
0.94 \\
\end{array}$ & $0.66-1.36$ & 0.754 & - & - & - \\
\hline $\mathrm{DM}$ & $\begin{array}{l}\text { No } \\
\text { Yes }\end{array}$ & $\begin{array}{l}1.00 \\
1.57\end{array}$ & $1.06-2.31$ & 0.023 & $\begin{array}{l}1.00 \\
0.97\end{array}$ & $0.60-1.55$ & 0.883 & - & - & - \\
\hline Hyperlipidemia & $\begin{array}{l}\text { No } \\
\text { Yes }\end{array}$ & $\begin{array}{l}1.00 \\
1.57 \\
\end{array}$ & $1.16-2.12$ & 0.003 & $\begin{array}{l}1.00 \\
1.33 \\
\end{array}$ & $0.92-1.91$ & 0.132 & - & - & - \\
\hline CKD Stage & $\begin{array}{l}1 \\
2 \\
3 \\
4 \\
5\end{array}$ & $\begin{array}{l}1.00 \\
0.53 \\
1.02 \\
3.74 \\
1.44\end{array}$ & $\begin{array}{l}0.33-0.84 \\
0.67-1.58 \\
1.65-8.46 \\
0.47-4.36\end{array}$ & $\begin{array}{l}0.007 \\
0.916 \\
0.002 \\
0.522\end{array}$ & $\begin{array}{l}1.00 \\
0.51 \\
0.73 \\
2.58 \\
1.02\end{array}$ & $\begin{array}{l}0.31-0.85 \\
0.45-1.20 \\
1.02-6.51 \\
0.30-3.43\end{array}$ & $\begin{array}{l}0.010 \\
0.216 \\
0.044 \\
0.980\end{array}$ & $\begin{array}{l}1.00 \\
0.50 \\
0.71 \\
2.43 \\
0.94\end{array}$ & $\begin{array}{l}0.30-0.83 \\
0.44-1.16 \\
1.00-5.92 \\
0.29-3.10\end{array}$ & $\begin{array}{l}0.008 \\
0.170 \\
0.051 \\
0.922\end{array}$ \\
\hline $\begin{array}{l}\text { Neoadjuvant } \\
\text { chemo }\end{array}$ & $\begin{array}{l}\text { No } \\
\text { Yes }\end{array}$ & $\begin{array}{l}1.00 \\
0.91\end{array}$ & $0.40-2.08$ & 0.815 & $\begin{array}{l}1.00 \\
0.87\end{array}$ & $0.34-2.20$ & 0.765 & - & - & - \\
\hline
\end{tabular}




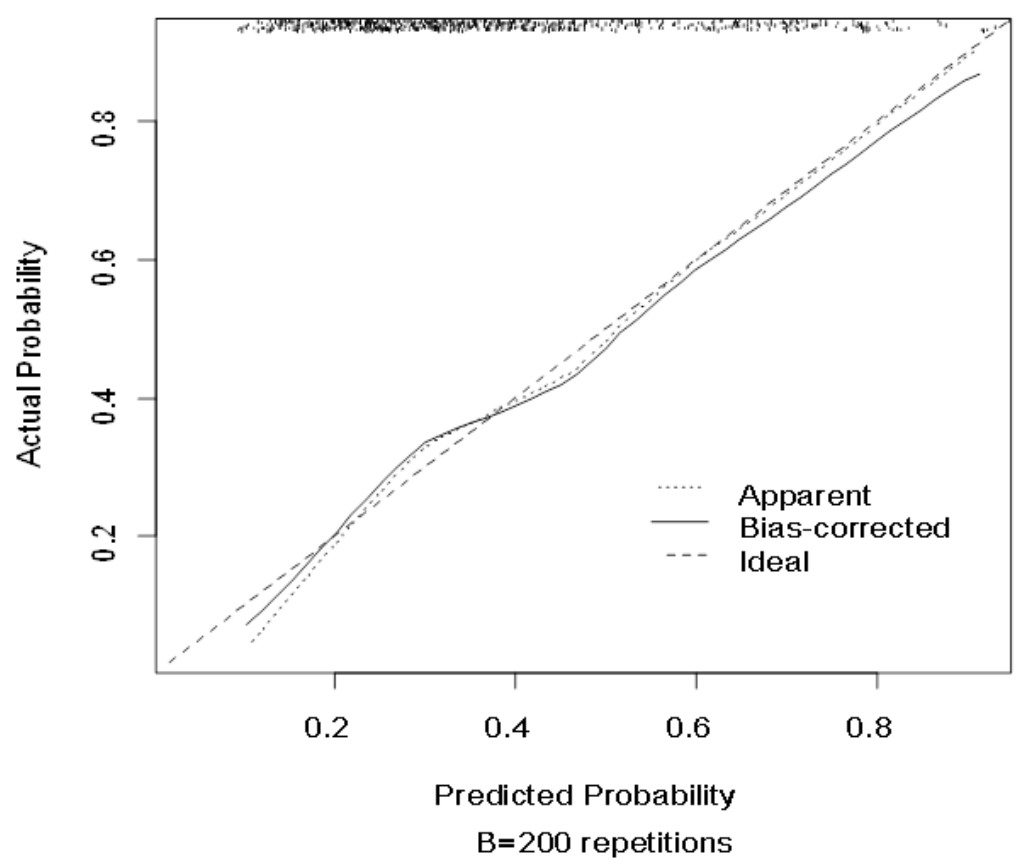

Points

Age

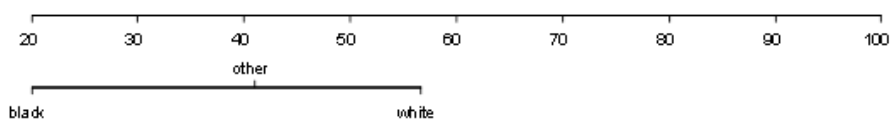

Race

ECOG PS

$\mathrm{CCl}$

CKD Stage

Total Points

Linear Predictor

Probability of Complication)

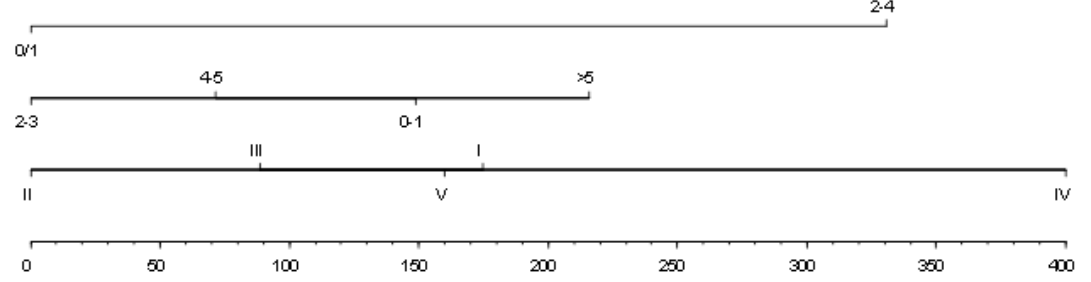

\begin{tabular}{|c|c|c|c|c|c|c|c|c|c|c|c|}
\hline-2.5 & -2 & -1.5 & -1 & .0 .5 & 0 & 0.5 & 1 & 1.5 & 2 & 25 & 3 \\
\hline & & & & & 0.5 & & 1.7 & & 0.9 & & 0.96 \\
\hline
\end{tabular}

